\title{
The Trilemma Revised:
}

\section{Harry Potter And A Landscape Of Moral Uncertainty}

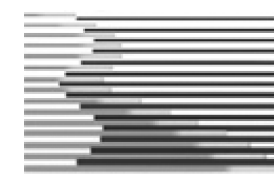

\section{Rebecca Ingalls}

Dept. of English and Philosophy, Drexel University, Philadelphia, PA USA

Poroi, 7,1 (January 2011)

In his discussion of the religious controversy that has orbited around J.K. Rowling and her Harry Potter novels, Andrew Blake (2002) makes the case that-unlike the books of C.S. Lewis and J.R.R. Tolkien-Harry Potter is devoid of "allegorized Christianity." Citing the books' lack of attention to Christmas as a spiritual event, the absence of a "superhuman power" that might protect the souls that Dementors are trying to devour, and the relativism of morality in the texts, Blake asserts, "Harry Potter isn't anti-Christian-the faith just isn't there" (2002, p. 95-96). The faithlessness of the novels, he argues, is what bonds them with others of the "post-Christian context" in which texts "work...precisely to stress the presence of the irrational and inexplicable in the contemporary world" (2002, p. 98-99). Blake posits that Rowling's books-while frightening to Christians-are reflections of today's "general crisis of faith" and are applicable to all people in that they dare to "deal with fundamental questions of human existence” (2002, p. 99).

While Blake makes an important argument about the novels' arrival in a cultural context that is rife with the questions, doubts, and disorder of postmodernism, he fails to recognize the uncannily similar thread of Christian rhetoric in the stories of Narnia and the Wizarding World of Harry Potter. Specifically, the "trilemma" - the three-part rationalization (Liar, Lunatic, Or Lord?) that Jesus was the Son of God, which Lewis illustrates in The Lion, the Witch and the Wardrobe (1950) - is ubiquitous in the adventures of Harry Potter. The multivalent question that haunts Narnia (Aslan's existence and resurrection as a Christfigure), also winds its way through the unfolding plot of the Harry Potter series, showing a flicker in the first book, emerging full force in Book Five, complicating itself further in Book Six, and reaching its culmination in Book Seven. 
What is particularly striking about the trilemma in the Harry Potter series, however, is that it is revised and leads the narrative down a different rhetorical path than the one found in the explicitly Christian stories of Narnia. Defying and confusing some traditionally stark boundaries between good and evil, mortal and immortal, Harry Potter is not Lewis's tidy story of clear ideological divisions or a clear rationalization of who-is-God and who-isn't-God. In Narnia, Lewis brings to life the story of Christ in terms easily translatable: Christ (or, Aslan), as the symbol of unconditional love and forgiveness, has died, has risen and will rise again. Edmund is the Judas character who turns himself around, and Aslan's (Christ's) identity as Lord is easily deduced in his sanity and honesty. Within the Harry Potter series, however, the narrative illustrates that Evil, too, in its myriad forms, can die, rise and return again; and no one is immune to doubt, mortality, or the temptation of "unforgivable curses."

Amid the texts' continued popularity (especially on the brink of the release of the last two films in 2010 and 2011), Christian resentment for the texts, and the ruins of Rowling's last book, we are compelled to ask, what is the message of Harry Potter? I argue that this rhetorical thread of the trilemma is critical to the composition of the Potter books as postmodern texts, and as tools to draw their readers into a conversation about what it means to negotiate today's social world outside of the texts. Indeed, as Blake (2002) suggests, the texts represent the "irrational" and "inexplicable" state of the world today. However, I assert that even amid such turmoil, there is faith to be found in the rhetoric of their message.

\section{Lewis's Trilemma: A Rational Argument}

We find C.S. Lewis's assertion that Jesus Christ was indeed the Son of God in his book Mere Christianity (1952), in which he writes:

A man who was merely a man and said the sort of things Jesus said would not be a great moral teacher. He would either be a lunatic - on the level with a man who says he is a poached egg - or he would be the Devil of Hell. You must make your choice. Either this man was, and is, the Son of God: or else a madman or something worse. You can shut Him up for a fool, you can spit at Him and kill him as a demon; or you can fall at His feet and call Him Lord and God (1952, p. 56). 
Lewis's three-part rationalization for Jesus-as-Lord is otherwise known as the "trilemma," as articulated by Josh McDowell in his 1980 book More Than a Carpenter, in which he cites Lewis's Mere Christianity as he builds his case for the argument that Jesus is the Son of God. Leaning heavily on logos, McDowell asserts that the "liar, lunatic, or Lord" "trilemma" should lead a potential believer to see that Jesus was not deliberately telling people untruths (based on his lifestyle, his "teachings" and his eventual crucifixion), and he was not insane (based on the profundity of his teaching), so 'logic' would suggest that he was who he said he was (1980, p. 25-35).

It is no secret that C.S. Lewis was, as Bruce Edwards (2005), C.S. Lewis scholar and author of Further Up \& Further In, articulates it, a "pioneer of faith" (p. 1). A convert to Christianity after a series of personal losses and a great distancing from his father during school-aged years spent in miserable boarding schools, Lewis sought to "pursue with a pure heart his real vocation of communicating the gospel in fresh and refreshing ways in multiple genres for a diversity of audiences" (Edwards, 2005, p. 5). Lewis's closing remarks in Mere Christianity encompass his larger message to readers: "Look for yourself, and you will find in the long run only hatred, loneliness, despair, rage, ruin, and decay. But look for Christ and you will find Him, and with Him everything else thrown in" (1952, p. 190). In inviting his readers to "look for Christ," Lewis endeavored to write Christ in accessible terms into his narratives. Edwards illustrates how in The Lion, The Witch and the Wardrobe Lewis constructs "inherently a spiritual world, a world informed by C.S. Lewis's Christian convictions and wise understanding of our fallen planet" (2005, p. 12). In his book, Jack: A Life of C.S. Lewis, George Sayer (1988) asserts that Lewis's "idea, as he once explained [to Sayer], was

to make it easier for children to accept Christianity when they met it later in life. He hoped that they would be vaguely reminded of the somewhat similar stories that they had read and enjoyed years before. "I am aiming at a sort of pre-baptism of the child's imagination" (1988, p. 318).

Using children's fantasy as his device, Lewis aimed to argue for what he believed to be the very reality that Jesus Christ was "man (just like you) and God (just like His father)" (Mere Christianity, 1952, p. 162). He hoped that-along with the myriad other memories implanted into the mind of the child in his youth-his 
stories would embed themselves and become part of the child's emerging and devoted faith.

\section{The Potter Controversy}

Though J.K. Rowling openly admits to no such religious agenda, since their debut the books have been contested between fundamentalist voices who believe them to be anti-Christian and even evil; those who partially defend the books as potentially evil but useful in preaching to children against evil; those who believe the books to be laden with moral teachings (though coinciding with Christian doctrine but not necessarily overtly Christian) and suitable texts for children; and those who argue that the books are obviously-and even deliberately-rich with Christian themes. Such a debate opens the door for rhetoricians to closely examine these texts and to unearth not only the potential messages they may be sending to a range of audiences, but also to identify the textual strategies that are used to send those messages. In a heated debate about banning books and teaching children about God-or not-it becomes not only intellectually interesting to compare and contrast the compositions of these texts, but also critically important to the ways in which we think about marketing them, teaching them in our classrooms, and using them to think seriously and meaningfully about how they might represent the context in which they have been written.

We might begin, then, with a look at some voices in the debate. Citing "good magic" as inherently evil in the Potter series, Jack M. Roper (2007), whose writing is largely dedicated to cult research, argues, "Periodically in our society, mystical heroes penetrate our culture. Harry Potter, an orphaned witch, is one such hero who has captured the innocent heart of many children. When such a hero uses evil as a problem solving tool, we need to be warned" ("Harry Potter: The Hero for Modern Witchcraft"). This article, which may be found on the Christian Broadcasting Network's web site in a section called, "The Harry Potter Controversy," is also accompanied by slightly contrasting arguments for the Potter novels as conduits for teaching the Christian Gospels. For example, even though she, too, believes that the books may be dangerous for those readers who are "easily led astray," Connie Neal (2007) attempts to find a middle space with the novels. In her article, "What Would Jesus Do with Harry Potter?" she suggests, "Jesus might read the Harry Potter stories and use them as starting points for parables. He might use kids' interest in the battle between good and evil to explain the ultimate battle between good and evil." 
On the other side of the 'definitely-evil' and 'potentially-evil' spectrum, there are others, though perhaps not as numerous, who see Rowling's books as thematic representations of Christian teachings. Some even believe them to be driven by a Christian agenda and suggest that the books are appropriate for children because they help to tell the Christian story. John Granger (2006), author of Looking for God in Harry Potter, is "convinced that the fundamental reason for the astonishing popularity of the Harry Potter novels is their ability to meet a spiritual longing for some experience of the truths of life, love, and death taught by Christianity but denied by secular culture" (2006, p. 2). While he admits that he initially would not let his own children read the books (2006, p. 4), Granger has come to believe through his own reading of them "that the Harry Potter stories 'sing along' with the Great Story of Christ is a significant key to understanding their compelling richness" (2006, p. 2, emphasis his). His position on this issue suggests that the novels fill a gap in faith that mainstream culture didn't even know it had.

\section{Rowling And Lewis: A “Kinship," A Departure}

Though fewer in number, scholarly and religious voices have emerged to assert that there are Christian links between Rowling's and Lewis's narratives: some draw comparative parallels, while others find critical points of departure. Indeed, Granger (2006) refers repeatedly to C.S. Lewis, and aligns his own Christian beliefs with those found in Mere Christianity (2006, p. xiii). In some similar ways, Joy Farmer (2001) cites myriad religious parallels between Rowling and Lewis. Sharply contrasting Blake's (2002) claim in the introduction to this article, she argues, "Given the moral and spiritual dimension of Rowling's books, it is no surprise that they contain almost as much religious allegory as The Chronicles" (2001, p. 58). Acknowledging their shared appreciation for "both benevolent and malign" magic, Farmer suggests that each author links magic back to the miracle stories of healing and replenishment in the Bible. She writes:

Jesus changes water into wine, feeds a multitude with five loaves and two fish, and restores a blind man's sight with spittle. Because the context is religious, these events are deemed miracles, not magic. Yet Lewis and Rowling both deliberately blur the distinction in such examples as Aslan's Table, whose feast is daily renewed and daily cleared away; the dishes in Hogwarts' Great Hall, which fill and empty (seemingly) by themselves; Lucy's "cordial which would heal almost every wound and every illness" 
[qtd. in Farmer]; and the tears of Fawkes the phoenix, which have similar curative powers (2001, p. 54).

Such examples of magic/miracles, Farmer argues, acknowledge the existence of the Divine, but do not take away from the fact that suffering and evil exist, as well (2001, p. 55-56).

Further, Farmer draws a direct link between Aslan and Harry Potter in their mutual representation of Christ. Citing his "mixed parentage," the rhetoric of chosen-ness that surrounds him, his instincts to protect his friends, and his "unique and miraculous survival of Voldemort's attack," Farmer argues that Harry, like Aslan, is meant to be a Christ-figure (2001, p. 58). Moreover, she suggests, Harry's mother's sacrifice of her own life so that he could live (a scene that might also bring to mind Mary's self-sacrifice), and the subsequent scar left on Harry's forehead from that lifesaving act, recalls the rhetoric of death and resurrection, and God's ultimate protection from evil, in the New Testament. Such a parallel, Farmer argues, constructs Harry to be "like Christ the Second Adam [who] represents all humanity" (2001, p. 59).

Likewise, in "The Search for 'Deeper Magic': J.K. Rowling and C.S. Lewis," Griesinger (2006) argues against the fundamentalist belief that the Potter novels are inherently evil, and instead asserts, "Paradoxically, while drawing on imagery and symbols associated with witchcraft and the occult, Rowling nevertheless incorporates into the magic of her vision ideas that are neither occultic nor pagan but decidedly Christian" (2006, p. 318, emphasis mine). Citing Lewis's discussion of the "Deep Magic" of Aslan's self-sacrifice in The Lion, the Witch, and the Wardrobe, Griesinger, like Farmer, argues that Rowling, too, implements her own version of "Deep Magic" with Lily Potter's sacrifice to save her son from Voldemort, and Harry's risking of his own life for the sake of others (2006, p. 326-327).

These parallels between characters and twists of the plot, I argue, are important similarities that should draw a reader in for a closer look at the way in which the texts grapple with and make arguments about more complex issues, like morality. Indeed, the conversation among scholars about how Rowling and Lewis take on Christian morality is divided between those who believe that the two series represent clear moral boundaries, and those who believe that Rowling's texts make such distinctions far less clear to readers. Griesinger stands with the former camp on this issue. In her response to those Christians who rail against the books for being "morally confusing, without clear boundaries between evil and good," she writes, "I do not see this confusion," outlining the myriad lessons in the book that demonstrate "learning and playing 
by the rules" and the reality of having to "struggle and make right choices" (2006, p. 324). She refers to Harry's first experience with the Sorting Hat as a dilemma that illustrates such a struggle: "Harry has to decide which group to follow. Who will his role models be, honest Gryffindors or conniving Slytherins?" (2006, p. 325). Griesinger's suggestion is that while Harry himself may struggle to find righteousness, binaries in "the battle between goodness and evil" (2006, p. 331) are clearly delineated. Matthew Dickerson and David O'Hara (2006) agree that the Potter texts reflect an "objective morality," and they point to Dumbledore as "the great hero of the books" (2006, p. 249). Specifically, they assert that "Rowling's Dumbledore is in the same company as the heroes of Lewis and Tolkien when he says that there is a battle and that everybody is on one side or the other" (2006, p. 247).

Contrasting these authors' claims about the presence of distinct moral coding in the Potter books, Rebecca Stephens (2003) argues the very opposite and, as I will illustrate, helps to set us up for a critical rhetorical analysis of the ways in which the texts utilize the trilemma as a device. In her discussion of the similarities and differences between the Wizarding World and Narnia, Stephens asserts that in Narnia, "the reader always knows where one world ends and the other begins" and the righteous Aslan seems to be in control of everything (2003, p. 55-56). In the Wizarding World, however, the "limitations" of Dumbledore suggest that he "is clearly no Aslan" (2003, p. 57), and the lack of a clear, morally righteous authority figure makes it so that "all of the forces of the good in the book are decentralized" and "power seems horizontal" (2003, p. 57). As such, anyone could take up either the reigns of good or evil, and "traditional power structures are actively subverted" (2003, p. 57-58). It is this lack of authority and moral unity, argues Stephens, that is likely the cause for many Christians' vehement opposition to the texts. Like Blake, Stephens asserts that "in a world where traditional rules are not working" Harry Potter is an artifact of a society that is morally and culturally fragmented, and the many modern readers who are drawn to the texts may find themselves represented in them.

Indeed, what we have in the Harry Potter series, I argue, is a world that is unraveling. While early books in the series may suggest either-or questions of rightness or wrongness that will ultimately be answered, the progression of the series reveals a critical departure from such clear binaries all the way to the last book and beyond. Lewis's work is especially helpful in this rhetorical examination of Rowling's texts because, like those of Lewis, Rowling's books utilize the trilemma as a rhetorical tool. However, while the trilemma works in Lewis's books to edify 
morality, it works in Rowling's to splinter it. The dilemmas of honest-versus-conniving, good-versus-evil that the Harry Potter novels present become part of a critically complex-even unanswerable-trilemma that asserts that it is not always easy or even possible to decipher righteousness from wickedness. Reflecting in many ways the "Liar, Lunatic, or Lord?" rationalization about who is ultimately the most benevolently and malevolently powerful, the Harry Potter texts employ a trilemma of a larger scope that invites Harry, the other characters, and the books' readers to ask, "Good, Bad, or Somewhere in the Middle?" This trilemma not only exists in an underlying question about faith and doubt as we seek to understand who Dumbledore, Harry, Voldemort, Snape and even the Wizarding World itself represent in Christian terms, but also in the ongoing, perhaps even nondenominational, question about who is fighting for which side of morality. By the end of Book Six, readers still don't know, and neither does Harry. By the end of Book Seven, the reader sees a mess of moral confusion, and an argument about "Deep Magic" that transcends the boundaries of Christianity into a more universal inquiry into the postmodern condition of today.

\section{Deciphering Ultimate Good: Echoes Of Lewis's Trilemma}

The foundation of this comparative/contrastive analysis of the religious rhetoric of Lewis's and Rowling's series begins with the critical parallels between characters, which eventually help to illustrate how their roles translate from Hogwarts back to Narnia. It's important to note, from the outset, that the books are similar in ways that may not directly relate to religious rhetoric at all; such similarities lead a critical reader to look for places where the books are connected beyond the surface level. In understanding the ethos of Harry Potter, we find that parallels between characters in Lewis's and Rowling's work lead to important shared-and perhaps divergent-values.

We can begin with the nebulous portals (perhaps, even, characters unto themselves) from which characters leave the real world to enter the magical worlds: the ordinary wardrobe, and the illusory "barrier between platforms nine and ten" (Rowling, 1997, p. 93) that is Platform Nine and Three-Quarters. Guarding these borders are two similar gatekeepers: Hagrid and Mr. Tumnus. Both are messengers that lead the child across the boundary between the real or Muggle world and that of Narnia or the Wizarding World. Certainly, too, we can compare the main child characters of the books - Lucy, Edmund, Susan and Peter, and 
Neville, Ron, Hermione and Harry — who as a foursome soldier on into the magical world as its preservers. We see definite parallels between Lewis's White Witch and Voldemort, both of whom represent a wickedness that intends to cleanse the world of goodness with an immortal evil. And we may compare Aslan to Dumbledore, both omniscient, God-like and serving as the core of righteousness, or "Deep Magic" (as Lewis articulates); or we may compare Aslan to Harry, who survives Voldemort's attempts to murder him and seems destined to fight against "evil" and to risk his life to save his friends.

Despite what seems to be ultimate destiny, however, the unfolding drama in the Wizarding World is far more morally cluttered than the mindfully organized Narnia that Lewis has constructed. This critical difference, however, may be found on common ground. Analysis of character parallels gives way to an even more compelling similarity between the narratives of Lewis and Rowing - the use of the "Liar, Lunatic, or Lord?" trilemma as a rhetorical device. First used by Lewis in The Lion, the Witch and the Wardrobe (1950), the trilemma works to help him communicate the story of Christianity. Narnia falls literally and figuratively under the burden of evil marked by eternal winter, no Christmas, and living beings turned into stone by the White Witch, and has a chance to be redeemed by Aslan and those who fight with him on the side of morality. In order to execute this redemption, however, Lucy, who first ventures through the wardrobe to Narnia, must convince her siblings that such a place exists. When Susan and Peter reject Lucy's story, they go to the Professor for advice. It is through the words of the Professor that we see Lewis's rationale most clearly. We read:

"Logic!" said the Professor half to himself. "Why don't they teach logic at these schools? There are only three possibilities. Either your sister is telling lies, or she is mad, or she is telling the truth. You know she doesn't tell lies and it is obvious that she is not mad. For the moment then and unless any further evidence turns up, we must assume that she is telling the truth" (1950, p. 51-52).

The Professor's words, as it turns out, amount to much more than the suggestion that Susan and Peter should merely have faith that Narnia exists.

Having faith, in Lewis's book, extends beyond the boundary between the wardrobe and Narnia, for Lewis's trilemma may later be seen in the character of Aslan. His first appearance to the children is by way of the Beaver's utterance, "They say Aslan is on the move - perhaps has already landed" (1950, p. 74). With the 
introduction of this character, Lewis constructs Aslan's ethos and turns directly to his readers to say,

And now a very curious thing happened. None of the children knew who Aslan was any more than you do; but the moment the Beaver had spoken these words everyone felt quite different. Perhaps it has sometimes happened to you in a dream that someone says something which you don't understand but in the dream it feels as if it had some enormous meaning - either a terrifying one which turns the whole dream into a nightmare or else a lovely meaning too lovely to put into words, which makes the dream so beautiful that you remember it all your life and are always wishing you could get into that dream again. It was like that now. At the name of Aslan each one of the children felt something jump in its inside. Edmund felt a sensation of mysterious horror. Peter felt suddenly brave and adventurous. Susan felt as if some delicious smell or some delightful strain of music had just floated by her. And Lucy got the feeling you have when you wake up in the morning and realize that it is the beginning of the holidays or the beginning of summer (1950, p. 74).

Such is the rhetorical power Lewis infuses into Aslan's character; the utterance of his name seems to bring each child's truth to the surface. Of course, as we see in the responses to Lucy's story, popular perception of Aslan is divided. Though his presence brings Spring to Narnia, there are many who fight for the White Witch against him and who believe, as the White Witch does, that Aslan is "the fool" (1950, p. 166). But Aslan is Lewis's messenger; he constructs Aslan as a Christ figure who sacrifices himself to save the traitor Edmund and, though humiliated, tortured, and killed by the White Witch and her masses of followers, dies gazing "up at the sky" (1950, p. 170) as if it were the Heavens, and is not long after resurrected. To Lucy's proclamations of "Oh, you're real, you're real! Oh, Aslan!" (as if she herself doubted), Aslan explains the "deeper" magic that has brought him back to life and proceeds to breathe life back into all of the creatures that the White Witch has turned to stone. By the end of the novel, the trilemma has been logically resolved. He is no liar, he is not a lunatic. He is Lord.

So, too, do we find the questions of the trilemma woven throughout the Potter series. In Book One of Harry Potter, Rowling first introduces readers to the disappearance of Voldemort after Harry's mother protects her son from his powers (and thus sacrifices her own life). Hagrid reflects, "Somethin' about you finished him, Harry" (1997, p. 57). From the very 
beginning of the first chapter of the first book of the series, Rowling has constructed Harry as a boy much more extraordinary than either Muggle or wizard. Through this branch of the narrative, and quite like Aslan, Harry is constituted as a kind of immortal figure who once survived death at the hand of ultimate evil. After Harry is delivered as an infant to the doorstep of the Dursleys, we learn that his survival has inspired a great wave of belief, and the rhetoric of celebration echoes the arrival of the Christ child. Harry, also wrapped in swaddling clothes, is exalted as a blessing to all: Rowling writes, "... at this very moment, people meeting in secret all over the country were holding up their glasses and saying in hushed voices: 'To Harry Potter - the boy who Lived!" (1997, p. 17).

However, not everyone in the Muggle or magical worlds is certain of Harry's extraordinary nature. While his reputation as an exceptional child precedes his own knowledge of his history, there are many who doubt or resist what Harry represents. Certainly, the Dursleys are essential in the construction of doubt; Mr. Dursley's absolute rejection of the onslaught of messenger owls and his subsequent retreat to "the broken-down house" (1997, p. 44 ) in the middle of the sea suggest his disbelief that Harry could be anything other than ordinarily mortal; indeed, he is perceived and treated as much less. Furthermore, Harry arrives at Hogwarts to mixed reviews. Draco Malfoy is far from impressed by Harry (though we might see his treatment of him as pure envy), and the Sorting Hat itself seems uncertain about whether Harry is, as Griesinger articulates in her article, an "honest" Gryffindor or a "conniving" Slytherin (2006, p. 325). If the Sorting Hat represents an all-knowing revealer of 'true' identity, then the question of whether Harry-so lauded by so many in the Wizarding World-is truthful or deceitful about who he is certainly invites one part of Lewis's trilemma into play. Though many rejoice unto Harry, as if he were indeed a savior, doubt about his genuineness is invited early on in the series. Perhaps he is a liar.

Sanity-the other piece of the trilemma-is called into question when we first meet Albus Dumbledore, who is believed by many to be the most powerful and righteous of all wizards, and the only one that Voldemort fears. Upon hearing Dumbledore's first words-"Before we begin the banquet, I would like to say a few words. And they are: Nitwit! Blubber! Oddment! Tweak!" - Harry asks Percy Weasley, "Is he - a bit mad?" to which Percy replies, "Mad? ...He's a genius! Best wizard in the world! But he is a bit mad, yes" (1997, p. 123). The significance of sanity as it applies to Dumbledore and not to Harry may, at first, seem unclear. However, we soon learn that Harry and Dumbledore have an 
indelible bond that begins in Book One and is carried all the way to the end of the series. Dumbledore becomes a father-figure for Harry, giving him James Potter's invisibility cloak, directly instructing him more than he does any other child, and defending him above all (even when Harry has broken rules). Before his death, Dumbledore has taken it upon himself to guard Harry with his own life, and to give him one-on-one lessons about the history of turmoil in the Wizarding World and wisdom about further unrest to come. By the end of Book Six, Harry has become not only the leader of Dumbledore's Army, but he has also set off to avenge Dumbledore's mysterious death at the hand of Snape and to challenge Voldemort himself. The relationship between Harry and Dumbledore recalls that of God and Christ-separate and the same. Thus, if Dumbledore himself is perceived as mad, Harry's intimacy with Dumbledore calls his own sanity into question.

But questions about Harry's sanity are not simply associated with Dumbledore, for the state of his own mental wellbeing is often subject to the scrutiny of his community. For example, in Book Two, Harry learns that he speaks Parseltongue, a form of snake communication that Slytherin and Voldemort also know. This knowledge is, perhaps, Harry's first introduction to what he will later learn is a kind of shared consciousness with Voldemort. Harry's scar blinds him whenever Voldemort is near or when he is doing evil deeds. Even more critical is Voldemort's breaking into Harry's mind in Book Five, which leads Harry to dream, and thus predict, Voldemort's evil doings, and which prompts Dumbledore to ask Snape to teach Harry Occlumency, "the magical defense of the mind against external penetration" (2003, p. 519). The fact that Harry is now sharing his mind with Voldemort begs questions not only about his mental health, but also about his trustworthiness.

Moreover, we see other evidence in the transition from Book Four to Book Five of the "Liar, Lunatic, or Lord?" question as it applies not only to Harry's immortal power, but also to the resurrection of Voldemort himself: Is Harry a liar? Is he a lunatic? Or does he really know that Voldemort is back? At the close of Book Four, only Harry will attest to Voldemort's murder of Cedric Diggory, and into Book Five we learn that doubt about his testimony is popular opinion. It is not until well over halfway through Book Five, when Harry agrees to an interview for The Quibbler in which he explains everything that happened the night that Voldemort "came back," that we see the public doubt lift. In response to the article, Fred reads Harry one of the letters that a member of the community has written in to the newspaper: "Says you don't come across as a mad person, but he really doesn't want 
to believe You-know-Who's back..." Another letter: "Little though I want to think He-Who-Must-Not-Be-Named has returned, I am forced to accept that you are telling the truth." And another letter, read by Ron: “...this one says you've got her converted, and she thinks now you're a real hero" (2003, p. 579-580). Harry is neither a lunatic nor a liar...then it must be true that the Dark Lord is back.

Still, many continue to doubt the legitimacy of Harry's word. Questions about whether Harry is mad or lying seem to morph into one, as the entire community is stricken by the dismantling of what were once clear truths. Wizards from all over experience the paranoia that "the boy who lived" could be an evil-doing lunatic, as well as the possibility that Harry is actually right about the doom to come. Rita Skeeter calls him "Disturbed and Dangerous" (2000, p. 611), the Ministry works to shut him up altogether, and after Voldemort murders Cedric Diggory at the end of Book Four, Harry's belief that Voldemort is back throws the community further into a tailspin of panic and disbelief that is uncannily similar to the conservative Christian panic about the books themselves. Harry is tried in Book Five for using magic outside of school to fend off dementors (which moves many on the jury to believe he is lying). Dolores Umbridge tortures Harry by forcing him to carve into his own skin, "I must not tell lies'... as long as it takes for the message to sink in" (2003, p. 266), as if Harry himself doesn't even know that he's lying. And, by the time we get to Book Six, questions about one boy's identity are large enough to permeate the media of the entire community. One newspaper reads, "Harry Potter: The Chosen One?" (2005, p. 39). Here, the rhetoric of chosen-ness links back to the Christ narrative.

Such controversy over who Harry is-is he a liar? Is he mad? Is he Chosen?-seems to create a clear parallel with the rationale that Lewis presents to his own readers: a reader knows that Harry is not lying about Voldemort's return; and a reader is led to see that even when Harry doubts his own sanity (as when he has peculiar dreams that leak into reality), he is not really insane. So, "logically," he must be the Chosen One. Certainly, one could argue that Harry is indeed a Christ figure, and that his struggle to figure out his identity does not suggest anything "morally confusing" about the books, but rather a series of either-or questions that he-and those in his community-will come to resolve. Perhaps, even, it could be argued that, like Lewis's texts, the Harry Potter books clearly delineate g(o)od and evil, presenting to the reader a world that is certainly in a state of unrest, but one that can be brought to right as cleanly as Spring comes to Narnia with the return of Aslan. 
And yet, while the trilemma's questions may exist in Harry Potter, they are not so clearly answered.

\section{Morality And Methods: The Trilemma Revised}

Further rhetorical analysis shows that the clear parallels between Rowling and Lewis become significantly blurred as the Harry Potter books progress, and ultimately revise the argument of the trilemma. This instability between good and evil, I argue, helps the texts to spin the trilemma in such a way that the question becomes less about whether or not Dumbledore is God or Harry is the Chosen One, and more about fundamental morality as it applies to anyone and everyone in today's society. While Lewis's power of elimination-indeed, his logos-aims to clearly name the ultimate good (if ___ is not true, and ___ is not true, then ___ must be true), the trilemma Rowling's texts employ invites the reality of uncertainty: it could be __ , it could be__ or it could be . All are possible. As clearly as the trilemma works in Lewis's texts to make an argument for Christian morality, it works in Rowling's texts to question morality in general.

The tidiness of binaries in the Harry Potter series is complicated by several destabilizing factors. First of all, we should address the fact that Harry escapes from death with the Dark Lord in his blood. Harry's lightning-shaped scar is symbolic for parts of himself that he cannot reconcile; the mark, in many ways, is a smaller scale version of a Harry Potter he hardly knows. Dumbledore explains to Harry that in surviving Voldemort's murder attempt, Voldemort "transferred some of his powers to [Harry] the night he gave [him] that scar" (1998, p. 333). In the books, Harry must come face to face with Voldemort on several occasions (much like Luke and Vader), and in the process must confront his own mortal identity. In being so much "like" Voldemort, Harry is quite unlike Lewis's Aslan; Harry's character is constructed to be much less purely good. Despite the fact that Harry seems to fight for righteousness, above the narrative hovers the question of whether or not Harry actually is as powerful as many have believed him to be. Such questions are further illustrated in the less pure parts of Harry: he copies Hermione's homework, he often breaks rules while at school and sneaks around using the Marauder's Map, he lets his anger get the best of him and "accidentally" practices magic on the Dursleys and Aunt Marge in the beginning of Book Three, he frequently gets into tussles with Draco and his cronies, and he acquiesces to adolescent lust and engages in a physically romantic relationship with Cho Chang and Ginny Weasley. Perhaps most significantly, at 
the end of Book Six , Harry vows, "I'm the one who's going to kill [Voldemort]" and alludes to hurting Snape "along the way" (2005, p. 651), a pledge that leads him on the deadly mission of Book Seven. While most of these traits might be considered simply mischievous and simply "human," Harry's decision to murder Voldemort and/or attack Snape are not in line with Christian doctrine. These departures from the path of righteousness complicate Harry's character significantly, and invite the idea that he is, in many ways, both "good" and "bad."

Returning now to the rhetoric of chosen-ness, we can go back and re-examine Harry's role as the Christ figure. Recalling the "Harry Potter: The Chosen One?" newspaper article, which foreshadows a mysterious "prophecy [that some think] names him as the only one who will be able to rid [them] of He-Who-MustNot-Be-Named" (2005, p. 39), we may find that, despite Dumbledore's certainty that Harry is chosen, the identity of "Chosen" may not completely belong to Harry. We have learned in Book Five, for example, that the prophecy partially suggests that Neville Longbottom may be a candidate. And even though Dumbledore assures Harry that Voldemort "chose [Harry], not Neville" and has paid the price for choosing the boy that has "power the Dark Lord knows not" (2003, p. 842-843), Dumbledore's credibility begins to waiver soon thereafter.

Later in Book Six and mainly in Book Seven, Rowling turns the trilemma toward the God-figure, Dumbledore, who has since Book Five slowly become the subject of popular doubt. His public ethos has been in jeopardy since he took Harry under his wing, defended him (despite his rule-breaking) against his professorial colleagues and in the presence of the jury in Book Five, and became his mentor. Numerous attempts made by the Ministry of Magic aim to take Dumbledore's headmaster authority away from him because many believe he is "getting old and losing his grip" (2003, p. 95), and the government itself seems torn between just and unjust practices. By the end of Book Six, disempowered and murdered like Aslan, like Christ, Dumbledore becomes the subject of the sacrificial death as the protective strength of Hogwarts and its headmaster falls into ruin; and the "dark and twisting path [Harry] saw stretching ahead for himself" (2005, p. 652) comes into view. In Book Seven, Dumbledore's core identity is called into question when his personal history with Grindelwald becomes public knowledge. Harry's confusion surfaces in the words, "Some inner certainty had crashed down inside him.... He had trusted Dumbledore, believed him the embodiment of goodness and wisdom. All was ashes" (2007, p. 360). By this point, Harry's connection to Dumbledore has weakened, and Harry is less of a 
Christ figure and savior to his community now, and more of a mercenary. This revision of the trilemma works to underscore Stephens's argument about conservative Christian panic over the texts: to many, the moral relativism of the texts represents an "assumed lack of control [that] stems from the idea that our world is crumbling because the proper order of things - the hierarchy of power with God and Christians on top - has been disturbed" (2003, p. 61). With so much unrest in the authoritative body of the Wizarding World, Harry's fight is, in many ways, personal, confused, and doubtful, which may drive some Christian readers away from seeing him as any kind of hero.

But certainty about Harry, his connection to Dumbledore, and the world he's trying to save has "crashed down" long before we are privy to Rita Skeeter's The Life and Lies of Albus Dumbledore. The events of Books One through Six reveal to us characters deemed "good" or even good-enough who use less-than-righteous tactics or even appear to assert less-than-noble values, which further destabilizes the clear binaries of good and evil. We have, for instance, seen the Ministry of Magic employ dementors morbid creatures that guard Azkaban and injure their prey by sucking their souls out of their bodies - to patrol and protect Hogwarts. It is the Ministry of Magic that begins to doubt Dumbledore's wisdom and authority, and we see evidence of its crumbling ethos in employing Percy Weasley, who stops communicating with his family and sides with those who are trying to unseat Dumbledore and expel Harry. Moreover, it is the Ministry, too, that sends Dolores Umbridge to Hogwarts to be the new Professor of Defense Against the Dark Arts in Book Five; she gets pleasure from torturing Harry to write lines with a pen that makes his skin bleed. While the Ministry itself, perhaps, has not yet turned "bad," there is anxiety about its agenda that begins in the early books and creeps over books Four, Five and Six like a storm. Every issue of Hermione's Daily Prophet suggests a new transgression, and the one reality that becomes clear in Book Six is that it is entirely possible that those who were deemed good may now be less so, if at all. In fact, many who fear the disconnectedness and destruction that is befalling their world are the ones who are helping to make it more fragmented.

Giving material and contemporary structure to this looming distrust is Hogwarts itself. Built to withstand evils wanting to enter from the outside, Hogwarts is intended to be a fortress. As Hermione explains, the school is “...bewitched... If a Muggle looks at it, all they see is a moldering old ruin with a sign over the entrance saying DANGER, DO NOT ENTER, UNSAFE" (2000, p. 166). However, we learn that there are many ways for evil to 
permeate its walls: by leeching onto a Hogwarts professor (Queril), in the form of an Animagus (Peter Pettigrew), by sneaking into one of the Tri-Wizard Tournament tasks (the Death Eaters and Voldemort), by working for the Ministry of Magic (Umbridge), or by being one of Dumbledore's loyal colleagues for many years (Snape). The school itself, rhetorically constructed as a fortress of protection for the children-its walls and staircases have a wisdom of their own, and Dumbledore has long been its headmaster and guardian-proves to be as porous as the morality of those who inhabit it, and here we see the fragmentation that is characteristic of a post-911 world outside of the book. Perhaps most symbolic of the castle's frailty is the scene following Dumbledore's murder, when Harry finds his dead body lying outside in the castle yard: Hogwarts has grown so weak that it can no longer protect its headmaster (2005, p. 608). When Harry, Ron, and Hermione return to Hogwarts in Book Seven, the castle is a battleground, as much a victim to the tyranny of corruption and Voldemort as any of the wizards who have been weak enough to give in to Dark Magic.

In the midst of this devastation, the reader-and Harry-are left with core moral questions at the close of Book Six. Was Dumbledore, "the greatest wizard Harry had ever, or would ever, meet" (2005, p. 608) misled in allowing Snape to work at Hogwarts for so long? Was he simply not as wise as so many students and wizards thought? Could it be that Snape really is as evil as he seems? Will the Ministry find its way back to just practices in overseeing the Wizarding World? Is Harry really going to commit the murders of Voldemort and Snape? Will Draco Malfoy, whom Harry now pities rather than hates, really fall to Voldemort? How do we know who is Good? Who is Bad? Such are the ambiguous questions that sit with Harry, with much of the Wizarding World, and with readers. Certainty about characters' morality has dissolved in the contested space between the monstrous and the seemingly innocuous. And while the pendulum of morality does not always swing so dramatically from one to the next, the narrative demonstrates that sometimes it does, and it isn't always clear when that shift will happen.

In Book Seven, these questions linger as the revision of the trilemma works to draw the narrative to its culmination, and as Dumbledore's ethos continues to dwindle even after his death, even after the close of the book. Harry is the secret keeper and leader of the "mission" Dumbledore has sent him on. Certainly, the mission itself and the Battle of Hogwarts would be a sham without the help of his peers, but Harry is the mental vessel in which scenes of past and future appear, and he is still the one who 
must defeat Voldemort, who is made to critically question Dumbledore's love for him, who is made Godfather to Tonks and Lupin's child, and who is "not supposed to survive" (2007, p. 691) Voldemort, but then lives to meet Dumbledore at and then descend from King's Cross, the books' metaphorical Heaven. Even with this certainty about Harry's chosen-ness lingering, however, the questions of the trilemma are unanswered by the one who we might have thought could answer them. In this Heaven we see Dumbledore as decidedly human: he has a past that is marked by his desire for "glory" and a Wizarding World that dominated that of Muggles; and, despite the wisdom that has so much been a part of his ethos as a great genius wizard, Dumbledore himself is not altogether certain about Harry's fate or about the future of his world.

\section{Redemption In Uncertainty}

However, this analysis of a trilemma revised offers some illumination, an answer to our question-what is the message of Harry Potter? - that does not attempt to force a happy ending, but rather acknowledges a unity among readers and a sense of hope. We see the culmination of the trilemma and of the argument of the texts after Dumbledore's admission of uncertainty. Before Harry leaves King's Cross and Dumbledore, he asks the old wizard, "Tell me one last thing. Is this real? Or has this been happening inside my head?" Dumbledore responds, "Of course it is happening inside your head, Harry, but why on earth should that mean that it is not real?" (2007, p. 723). And in this exchange there is an expression of faith. In the last chapter in the series is Rowling's own articulation of "Deep Magic," which Lewis sought to ingrain in his young readers' minds. Aptly titled, "The Flaw in the Plan," the last chapter before the epilogue presents a scene reminiscent of ObiWan's fight with Vader, and Harry seems to know in this last battle after the battle that he must take on Voldemort alone. What is revealed in the exchange between Harry and Voldemort, however, is not Harry's chosen-ness per se, but rather the power that has fueled Harry's survival-love, remorse, faith. In today's society, such words are fluid, and intimately defined and redefined by those who use them. In fact, in an online post to readers asking about Neville's possible chosen-ness, Rowling assures her readers that Voldemort chose Harry, but that this act should not be looked upon as an act of fate. Rather, she argues, "destiny is a name often given in retrospect to choices that had dramatic consequences" ("F.A.Q. About the Books"). In other words, the paths of good and bad are up to us as humans to decide, we cannot predict the paths 
that we or others will take, and we cannot necessarily define for others what is "good" and what is "bad."

At the close of the series, Voldemort has unexpectedly murdered himself, and Harry has chosen the path of mortality. The cheery epilogue, which depicts Harry's life with Ginny and the happy, successful adulthoods of the series' characters, doesn't quite mollify the melancholy of what has happened only pages before; there is very little victory in the disappearance of Voldemort, and the inquiry of the trilemma still hovers. It is not altogether certain that his Dark Magic is gone for good, as the weight of the seven books sits heavily in its own questions about what will become of the Wizarding World. The books' characters, like its readers, are very much steeped in the uncertainty of today's world, and neither the end of battle, nor the tying of knots, nor the healing from loss will order the disarray.

But there is redemption to be found in the rhetoric of the revised trilemma. Though they may offer readers a darker, less certain world than the Narnia that Lewis creates, Harry Potter does present us with a world that is current, human, and, perhaps, more applicable to its vast audience of today's readers. Stephens suggests that "the Harry Potter debate is a microcosm of our cultural debates about how to live with diversity and change," and that the debate itself has created "a point of connection" for people of all kinds (2003, p. 63). I argue that the big questions that the trilemma poses, and that Harry Potter seeks to address, problematize, and leave open, help not only to give people something to argue about together, but also to offer some hope in the face of uncertainty.

The revision of the trilemma also underscores one of the tenets of Christianity: faith despite struggle. In Mere Christianity, Lewis asserts that the Christian life is not easy, and that those who seek it "must not be surprised if we are in for a rough time...the process will be long and in parts very painful; but that is what we are in for" (1952, p. 174-175). In the Christian life there are many obstacles to walking that path. This doctrine, however, need not necessarily be seen as solely Christian. While Griesinger argues that Rowling's narrative "sets the stage for the Christian gospel and provides readers a 'real though unfocused gleam of divine truth"” (2006, p. 331), we might also see Harry Potter's stage as humanity itself. In negotiating the trilemma of Good, Bad, or In Between? we are all navigating a moral landscape, regardless of its religious specificity. In many ways, Harry Potter's characters ask specific questions about the existence of God and the ultimate truths of right and wrong, but more broadly, they invite us all to 
ask ourselves how we know goodness or evil when we see it. In so doing, they acknowledge that sometimes morality does not answer to logic.

\section{References}

Blake, Andrew. The Irresistible Rise of Harry Potter. New York: Verso, 2002. Print.

Dickerson, Matthew, and David O'Hara. From Homer to Harry Potter: A Handbook on Myth and Fantasy. Grand Rapids, MI: Brazos Press, 2006. Print.

Edwards, Bruce. Further Up \& Further In: Understanding C.S. Lewis's The Lion, the Witch and the Wardrobe. Nashville, Tennessee: Broadman \& Holdman Publishers, 2005. Print.

Farmer, Joy. "The Magician's Niece: the Kinship between J.K. Rowling and C.S. Lewis." Mythlore 88 (Spring 2001): 53-64. Print.

Granger, John. Looking for God in Harry Potter. Carol Stream, IL: Tyndale, 2006. Print.

Griesinger, Emily. “The Search for 'Deeper Magic': J.K. Rowling and C.S. Lewis." The Gift of Story: Narrating Hope in a Postmodern World. Eds. Emily Griesinger and Mark Easton. Waco, Tx.: Baylor University Press, 2006. 317-331. Print.

Lewis, C.S. The Lion, the Witch and the Wardrobe. New York: HarperCollins, 1950. Print.

---. Mere Christianity. New York: Macmillan Publishing Co., Inc., 1952. Print.

McDowell, Josh. More Than a Carpenter. Wheaton, Ill.: Tyndale House Publishers, 1980. Print.

Neal, Connie. "What Would Jesus Do with Harry Potter?" Christian Broadcasting Network. 2007. Web. 27 July 2010.

Roper, Jack M. "Harry Potter: the Hero for Modern Witchcraft." Christian Broadcasting Network. 2007. Web. 27 July 2010.

Rowling, J.K. Harry Potter and the Chamber of Secrets. New York: Scholastic Press, 1998. Print.

---. Harry Potter and the Deathly Hallows. New York: Scholastic Press, 2007. Print.

---. "F.A.Q. About the Books.” J.K. Rowling Official Site. Warner Brothers Enterprises. Web. 3 May 2009. 
---. Harry Potter and the Goblet of Fire. New York: Scholastic Press, 2000. Print.

---. Harry Potter and the Half-Blood Prince. New York: Scholastic Press, 2005. Print.

---. Harry Potter and the Order of the Phoenix. New York: Scholastic Press, 2003. Print.

---. Harry Potter and the Prisoner of Azkaban. New York: Scholastic Press, 1999. Print.

---. Harry Potter and the Sorcerer's Stone. New York: Scholastic Press, 1997. Print.

Sayer, George. Jack: A Life of C.S. Lewis. Wheaton, Ill.: Crossway Books, 1988. Print.

Stephens, Rebecca. "Harry and Hierarchy: Book Banning as a Reaction to the Subversion of Authority." Reading Harry Potter: Critical Essays. Ed. Giselle Liza Anatol. Westport, CT: Praeger Publishers, 2003. 51-65. Print. 